\title{
Theory and Practice in the Music of the Islamic World
}

This volume of original essays is dedicated to Owen Wright in recognition of his formative contribution to the study of music in the Islamic Middle East. Wright's work, which comprises, at the time of writing, six field-defining volumes and countless articles, has reconfigured the relationship between historical musicology and ethnomusicology. No account of the transformation of these fields in recent years can afford to ignore his work. Ranging across the Middle East, Central Asia and North India, this volume brings together historical, philological and ethnographic approaches. The contributors focus on collections of musical notation and song texts, on commercial and ethnographic recordings, on travellers' reports and descriptions of instruments, on musical institutions and other spaces of musical performance. An introduction provides an overview and critical discussion of Wright's major publications. The central chapters cover the geographical regions and historical periods addressed in Wright's publications, with particular emphasis on Ottoman and Timurid legacies. Others discuss music in Greece, Iraq and Iran. Each explores historical continuities and discontinuities and the constantly changing relationships between music theory and practice. An edited interview with Owen Wright concludes the book and provides a personal assessment of his scholarship and his approach to the history of the music of the Islamic Middle East. Extending the implications of Wright's own work, this volume argues for an ethnomusicology of the Islamic Middle East in which past and present, text and performance are systematically in dialogue.

Rachel Harris is Reader in the Music of China and Central Asia at SOAS, University of London, UK. Her research interests include global musical flows, identity politics, gender and ritual practice. She is the author of two books on musical life in China's Xinjiang Uyghur Autonomous Region, and co-editor of three books. She currently leads an AHRC Research Network and the Leverhulme Research Project "Sounding Islam in China". She is actively engaged with outreach projects relating to Central Asian and Chinese music, including recordings, musical performance and consultancy.

Martin Stokes is King Edward Professor of Music at King's College London, UK. He has taught ethnomusicology at Queen's University Belfast, the University of Chicago and Oxford. He is the author of The Arabesk Debate: Music and Musicians in Modern Turkey (1992) and The Republic of Love: Cultural Intimacy and Turkish Popular Music (2010). His edited volumes include Ethnicity, Identity and Music (1994) and (with Karin Van Nieuwkerk and Mark LeVine) Islam and Popular Culture (2015). 


\author{
SOAS Musicology Series \\ Series Editor: \\ Keith Howard, SOAS, University of London, UK
}

The study of the world's many and diverse music cultures has become an important part of the discipline of musicology. Often termed 'ethnomusicology', the resulting studies share the fundamental recognition that music is cherished by every society in the world. Like language, music is a universal means of individual and cultural expression. It is also infinitely varied. Music in any society has intrinsic value in its own right, and can tell us much about the culture in which it developed. The core of the SOAS Musicology Series comprises studies of different musics, analysed in the contexts of the societies of which they are part, and exploring repertories, performance practice, musical instruments, and the roles and impacts of individual composers and performers. Studies which integrate music with dance, theatre or the visual arts are encouraged, and contextualised studies of music within the Western art canon are not excluded.

Reflecting current ethnomusicological theory and practice, the editors recognize the value of interdisciplinary and collaborative research. Volumes may utilize methodologies developed in anthropology, sociology, linguistics and psychology to explore music; they may seek to create a dialogue between scholars and musicians; or they may primarily be concerned with the evaluation of historical documentation. Monographs that explore contemporary and popular musics, the effect of globalization on musical production, or the comparison of different music cultures are also welcomed.

\title{
Recent titles in the series:
}

The Women of Quyi

Francesca R. Sborgi Lawson

The Music of Malaysia

Patricia Matusky and Tan Sooi Beng 


\section{Theory and Practice in the Music of the Islamic World}

Essays in Honour of Owen Wright

\section{Edited by Rachel Harris and Martin Stokes}


First published 2018

by Routledge

2 Park Square, Milton Park, Abingdon, Oxon OX14 4RN

and by Routledge

711 Third Avenue, New York, NY 10017

Routledge is an imprint of the Taylor \& Francis Group, an informa business

(C) 2018 selection and editorial matter, Rachel Harris and Martin Stokes; individual chapters, the contributors

The right of Rachel Harris and Martin Stokes to be identified as the authors of the editorial material, and of the authors for their individual chapters, has been asserted in accordance with sections 77 and 78 of the Copyright, Designs and Patents Act 1988.

All rights reserved. No part of this book may be reprinted or reproduced or utilised in any form or by any electronic, mechanical, or other means, now known or hereafter invented, including photocopying and recording, or in any information storage or retrieval system, without permission in writing from the publishers.

Trademark notice: Product or corporate names may be trademarks or registered trademarks, and are used only for identification and explanation without intent to infringe.

British Library Cataloguing-in-Publication Data

A catalogue record for this book is available from the British Library

Library of Congress Cataloging-in-Publication Data

Names: Wright, Owen, honoree. | Harris, Rachel (Rachel A.) editor. |

Stokes, Martin, editor.

Title: Theory and practice in the music of the Islamic world : essays in honour of Owen Wright / edited by Rachel Harris and Martin Stokes.

Description: Abingdon, Oxon ; New York, NY : Routledge, 2017. | Series:

SOAS musicology | Includes bibliographical references and index.

Identifiers: LCCN 2016054627 | ISBN 9781138218314 (hardback) | ISBN 9781315191461 (ebook)

Subjects: LCSH: Music_-Islamic countries-History and criticism.

Classification: LCC ML55.W95 2017 | DDC 780.917/67—dc23

LC record available at https://lccn.loc.gov/2016054627

ISBN: 978-1-138-21831-4 (hbk)

ISBN: 978-1-315-19146-1 (ebk)

Typeset in Times New Roman

by Apex CoVantage, LLC

Bach musicological font developed by (C) Yo Tomita 


\section{Contents}

List of figures $\quad \mathrm{x}$

List of tables $\quad$ xii

List of music examples xiii

Preface xiv

List of contributors $\quad$ xvi

Introduction - tuning the past: the work of Owen Wright $\quad \mathrm{xx}$

MARTIN STOKES

\section{PART I}

Ottoman legacies 1

1 New light on Cantemir 3

ECKHARD NEUBAUER

2 Towards a new theory of historical change in the Ottoman instrumental repertoire

JACOB OLLEY

Introduction 22

The Kevseri Mecmuasl 22

The nineteenth century 23

Melodic density: regular and irregular rates of change 24

Formal structure and tempo retardation 30

Rhythmic augmentation and melodic density 32

Conclusion 35

3 Not just any usul: semai in pre-nineteenth-century performance practice

MEHMET UĞUR EKINCI

An usul of many kinds 43

Multiple versions of melodies 44 
vi Contents

Pre-nineteenth-century descriptions 50

Recent evidence 52

Was semai an "ovoid" rhythm? 56

Conclusion 58

4 Itri's "Nühüft Sakil" in the context of Sakil peşrevs in the seventeenth century

WALTER ZEV FELDMAN

Issues of makam and usul: nühüft 75

Issues of makam and usul: sakil 76

Conclusion 80

5 Giambattista Toderini and the "Musica Turchesca"

GIOVANNI DE ZORZI

The Venetian context 85

European travellers and their observations of Ottoman music 87

Toderini's chapter on music 87

On the musical instruments played by the Turks 92

Essay in Turkish music 94

6 At the House of Kemal: private musical assemblies in

Istanbul from the late Ottoman Empire to the

Turkish Republic

PANAGIOTIS C. POULOS

The meclis in the Ottoman urban context 107

Bureaucratic and other legacies 111

Sensorial assemblages 115

Conclusion: Republican musical legacies 118

7 Kâr-ı nev: elongation and elaboration in recordings of a Turkish classic

JOHN O'CONNELL

The kâr 125

The kâr-1 nev 128

Ismail Dede Efendi 130

A new type of kâr 131

Münir Nurettin Selçuk 132

Kâr-1 nev in concerts 134

Kâr-1 nev on recordings 135

Elongation and elaboration 137 
Versions and editions 139

Owen Wright 140

8 Measuring intervals between European and "Eastern" musics in the 1920s: the curious case of the panharmonion or "Greek organ"

ELENI KALLIMOPOULOU

Between the Church and the theatre 148

Between practice and theory, the oral and the written 153

Between East and West 155

Between Athens and Istanbul: an enlarged vision of

Greekness 158

The cosmopolitan vision of Eva Palmer Sikelianos 160

Epilogue 163

\section{PART II}

Historical and theoretical themes in the music of the Islamic world

9 "Words without songs": the social history of Hindustani song collections in India's Muslim courts c.1770-1830

KATHERINE BUTLER SCHOFIELD

The music connoisseur's collection 179

A colonial repertoire? 182

The "authoritative" Mughal repertoire 187

Conclusion 190

10 The music of the Timurids and its legacy in Afghanistan JOHN BAILY

The Timurid court of Herat 199

Transmission to neighbouring regions 206

Khorasani music in eighteenth-century Afghanistan 209

Inputs from Hindustan 210

Khorasani music in Herat in the twentieth century 211

Conclusions 213

11 Theory and practice in contemporary Central Asian maqūm traditions: the Uyghur On Ikki Muqam and the Kashmiri Sūfyāna Musīqī

RACHEL HARRIS

Contemporary repertoire 217 
viii Contents

Central Asian theoretical traditions 218

Processes of canonization 220

Cosmopolitan courts and Sufi shrines 221

Ashiq and the On Ikki Muqam 227

Musical style and instrumentation 228

Conclusion 232

12 The terminology of vocal performance in Iranian Khorasan

STEPHEN BLUM

Announcing, eliciting and describing vocal actions 239

Calls and responses 240

Sources of sounds and voices 241

Combinations of noun and verb 244

Dāstān and shabih 246

13 Whispering to God: monājāt, a sung prayer in Iranian Khorasan

AMENEH YOUSSEFZADEH

Monājāt as a genre of supplicatory prayer 253

Khorasan as a centre of Sufism 255

Monājāt in eastern and northern Khorasan 256

Transmission 258

Poetic forms and melodic types (maqām or āhang) 259

Examples of monājāt from Khorasan 260

Conclusion 265

14 Between formal structure and performance practice: on the

Baghdadi secular cycles

SCHEHERAZADE HASSAN

Iraqi Maqams in the structure of the secular cycle 273

Iraqi cycles versus Arab Middle Eastern cycles 274

The structural model of the Iraqi secular cycles, fusuul

al-maqāmāt al-irāqīyya 275

The secular Great Cycle fușul al-maqāmāt al-irāqīyya as a

point of reference 277

The five medium cycles, fașils 277

The sub-cycle as model 279

Evolution of the secular cycles towards free cycles 281

The disintegration of the traditional cycles 282

On the function of the cycle and its genres 283

The content of the cycles: central and associated forms 284

Instruments and instrumental genres 285 
Giovanni DE ZORZI - University "Ca' Foscari" of Venice - 22/01/2018

Contents ix

Cycles and performance practice 285

Conclusion 286

15 Al-Fārābī's polychord: a re-exposition of Ptolemy's kanōn as a didactic instrument for the tone system

GEORGE SAWA

Postlude: interview with Owen Wright

RACHEL HARRIS

Owen Wright: full bibliography

Glossary

314

Index

318 


\section{Figures}

5.1 Comparison between Italian and Turkish pitches, with tanbûr tablature, from Toderini 1787

Courtesy of Ministero dei Beni e delle Attività Culturali e del Turismo - Biblioteca Nazionale Marciana

5.2 Concerto turco nominato Izia Saz Semaisi

Courtesy of Ministero dei Beni e delle Attività Culturali e del Turismo - Biblioteca Nazionale Marciana

5.3 Frontispiece of the Letteratura Turchesca with musical instruments and scores

Courtesy of Ministero dei Beni e delle Attività Culturali e del Turismo - Biblioteca Nazionale Marciana

7.1 Musical setting of the kâr-ı nev

7.2 Selçuk with members of the Darü'l-Feyz-i Mûsiki (c.1914) 134

7.3 Temporal setting of the kâr-ı nev

8.1 Photograph of the panharmonion keyboard

Benaki Museum/Historical Archives, Eva Sikelianou Archive 189/27

8.2 Psachos and the panharmonion

Oetingen, 1922-1924; ELIA-MIET Photographic Archive

8.3 Eva Palmer Sikelianos in the 1910s ELIA-MIET Photographic Archive

9.1 A khayāl in Brajbhasha and a tappa in Panjabi, both in Rag Bhairav. Richard Johnson Songs (c.1780-1785), f. 2r

9.2 The beginning of the "night rāgs and rāginīs" section of the contents table (fihrist) of the Rāg-Rāginī Roz o Shab (f. 5v), showing Hamir ("pages 1-6: 36 dhrupads and so forth, 6 horis 18 khayāls and so forth"), Jit and Kedara.

Courtesy of the Salar Jung Museum, Hyderabad

$9.3 \operatorname{sargam}(\mathrm{L})$ and tarānā (R), Plowden Album (1787-1788), ff. 36, 35.178

(C) The Fitzwilliam Museum, Cambridge

9.4 List of Johnson's important Hindustani musical MSS in the

British Library

9.5 Correlation of Plowden texts with their tunes 
9.6 Refrain of the Hafiz ghazal "Mutrib-i khwush-navā begū" (Plowden tune-book, f. 12r)

11.1 Map of Central Asia and Tibet, 1894-1908, made by European explorer Sven Hedin. Detail showing Yarkand and Srinagar

11.2 Tokhti Ashiq, Khotan, 2016 Photo courtesy of Mu Qian

11.3 Dolan musicians. From left to right: Äkhät Tokhti plays rawap, Imir Ämär plays qalun, and Sidiq Osman plays ghijäk. Mäkit, 2013229 Photo courtesy of Mukaddas Mijit

11.4 Mushtaq Ahmad Saznawaz plays the sāz-e-kashmīr $\bar{\imath}$ 


\section{Tables}

1.1 Sequence of maqâms with the number of their associated peşrev compositions in the Tehran Collection, Mellî 2804, and according to the material in the theoretical section of the Istanbul Cantemir collection

1.2 Sequence of peşrevs in maqâm 'irâk in the Mellî (Tehran) collection compared with the collections attributed to Kevserî (Collection I) and Cantemir

1.3 The sequence of maqâms and the number of peşrevs in the collections of Tehran, Mellî 2804, Kevserî I and II and İstanbul Üniversitesi Kütüphanesi, T.Y. 1856

1.4 Comparative listing of sema $\hat{\imath}$ compositions from the four sources 13

1.5 Compositions attributed to Demetrius Cantemir 14

2.1 Melodic densities of pieces in devr-i kebir 25

2.2 Melodic densities of pieces in other rhythmic cycles (including pieces from the Kevseri Mecmuasi)

2.3 Comparison of total numbers of cycles

$3.13 \mathrm{k}$-beat Semai having $5 \mathrm{k}$-beat versions in post-eighteenth-century sources

3.2 Melodic differentiation between contemporaneous versions of pieces

3.3 Relationship among the structural elements of Semai 59

12.1 Some Persian nouns for vocal sounds and sequences of sounds 245

12.2 Verbs used with several of these nouns 245

14.1 The sequence of Iraqi maqâms in the five fașils 276

14.2a The first cycle: al-faṣl al-awwal-fașl al-beyāt $\quad 279$

14.2b The second cycle: al-faṣl al-thān̄ - fașl al-hijāz $\quad 279$

14.2c The third cycle: al-fașl al-thālith - faṣl al-rest $\quad 279$

14.2d The fourth cycle: al-fașl al-rābi' - faṣl al-nawā $\quad 280$

14.2e The fifth cycle: al-faṣl al-khämis - fașl al-husayñ̄ 280

14.3 The sub-cycle: basic structure and performance 281 


\section{Music examples}

2.1 First two cycles of AU70, C54 and K434 23

2.2 First two cycles of K434 and first four cycles of IÜ1-51 26

2.3 First two cycles of C290 and first four cycles of IÜ1-2 28

2.4 Continuation of mülazime of K490 and second hane of IÜ1-16 29

2.5 First two cycles of İ̈̈1-51 and Ï̈1-69 34

3.1 "Hüseyni Semai" 46

3.2 "Neva Semai" $\quad 47$

3.3 "Suzidilara Semai" 48

3.4 "Acem Semai", initial measures of each section 49

3.5 "Irak Semai", initial measures of each section 49

3.6 "Rast/Rehavi Semai", corresponding sections 50

3.7 "Dügah/Hüseyni Semai", first two sub-sections (terkîb) 54

3.8 "Nühüft/Isfahan Semai”, first sub-section (terkîb) 54

4.1 "Rast Sakil", Papa Ferruh, Serhane (Cantemir no. 127) 77

4.2 "Pençgah Sakil", Ağa Mumin, Serhane (Cantemir no. 128) 78

4.3 "Peşrev-i Kantemir Han, Der Makam-1 Mezbur (neva)", Sakil, Serhane (Ali Ufkî, Местиа p. 102) 79

4.4 "Hüseyni Subh-i Sahar", Cedid (Cantemir no. 198) 79

4.5 Nühüft, Sakil, Itri (Cantemir) 80

7.1 Musical transcription of the kâr-ı nev 126

11.1 Melodic detail in sāz-e-kashmīrī performance 230

11.2 Nawa muqam, muqüddimä (excerpt), instrumental version
performed on the bowed diltar lute by Abdulla Mäjnun

11.3 Rak Muqam, first mäshräp, excerpt, sung by Abdulla Mäjnun (transcribed an octave above actual pitch)

11.4 Segah Maqām, setāla, excerpt, sung by Ustad Muhammad Yaqoob Sheykh and his students, Srinagar 2013 (transcribed an octave above actual pitch) 232

13.1 Monājāt-e Musā 264 


\section{Preface}

The idea of a volume paying tribute to Owen Wright's scholarship had been around for some time before this particular initiative took shape. We should not have been surprised, then, that the first round of emails produced a positively worrying level of response. How on earth were we to fit everything in? It would have been very easy to imagine a volume at least twice the size of the present one. In the event, not everybody could contribute. Among those not able to, the following would like to add their names to those represented in this volume, as a mark of their respect for Owen's friendship and scholarship: Hooman Asadi, Evrim Binbaş, Saida Daukeyeva, Ruth Davis, Rich Jankowsky, Angelika Jung, Laudan Nooshin, Edwin Seroussi, Federico Spinetti and Will Sumits. They are part of this volume in spirit. Thanks also to Emma Gallon for the Routledge SOAS Musicology series, to the two anonymous reviewers and to Anna Contadini for her advice throughout the process.

\section{A note on the orthography and transliteration}

Editing a volume of this nature, spanning the music of Arab, Ottoman Turkish, Persian and Central Asian worlds and from the Middle Ages to the present day, involves some formidable orthographic and transliteration problems. Common names and technical terms are often rendered quite differently in the various (national and disciplinary) traditions of scholarship represented here and even over the course of time in the work of a single author. Scholarship demands accuracy in these matters, of course, but the general musicological reader, a reader who might not, for instance, be a scholar of Middle Eastern languages, also has legitimate demands - for recognizable and pronounceable versions of common terms and names, for instance, and for a measure of consistency across the text. We have aimed for a balance. Individual contributors have generally been guided by IJMES and stylistic norms in their own traditions of scholarship (philological, musicological, anthropological, ethnomusicological and so forth), as well as their own tastes in such matters. Common and recurrent names (Cantemir, Ali Ufkî, Maraghi) have been harmonized across the volume, favouring simple, recognizable versions. Technical terms have been a more complicated matter. Here, we have attempted to harmonize different versions regionally, but not impose uniformity 
where the same term might mean something different in different contexts or simply look or feel out of place. So, in the Turkish contexts, makam and gazel, in South and Central Asian contexts, maqām and ghazal. We have also avoided, where possible, Arabic, Turkish and Persian plurals, preferring the English -s. So makams and maqūms rather than makamlar or maqūmāt. Inevitably there will be some inconsistencies and errors of judgement. But we ask the reader to be tolerant and, where in doubt, to consult the glossary or index where, we believe, many (if not most) of these matters will be resolved. 


\section{Contributors}

John Baily, Emeritus Professor of Ethnomusicology, Goldsmiths. John Baily came into ethnomusicology from experimental psychology. During a Research Fellowship at Queen's University of Belfast, he conducted two years of ethnomusicological fieldwork in Afghanistan before being appointed Lecturer in Ethnomusicology at Queen's. He trained in anthropological film-making at the National Film and Television School. He was Associate Professor in the Centre for Ethnomusicology, Columbia University, New York, before joining Goldsmiths in 1990, where he is now Head of the Afghanistan Music Unit. He has published numerous books, articles and films on Afghan music and is a respected performer on the Afghan rubab.

Stephen Blum, Professor, City University of New York Graduate Center. Research interests include music of West and Central Asia and ethnomusicological analysis. He joined the Graduate Center faculty in 1987, when the concentration in ethnomusicology was initiated. He has published several articles, books, and encyclopedia articles on general topics (composition, improvisation, music analysis, modern music history, cultural exchange) and on specific musical practices of Iran, Kurdistan, Central Asia, Europe and North America. He has been active in the Society for Ethnomusicology and currently serves on the editorial boards of the British Journal for Ethnomusicology and the Journal of the American Musicological Society.

Giovanni de Zorzi, Lecturer, University of Venice. Giovannni de Zorzi holds a $\mathrm{PhD}$ in ethnomusicology. In December 2011 he was appointed Researcher and Lecturer in Ethnomusicology at the Ca' Foscari University of Venice. His main research areas are the Ottoman-Turkish, Iranian and Central Asian traditions of classical and Sufi music. His activities alternate between musical performance as a ney flute player, and field research, writing, musical and academic teaching.

Mehmet Uğur Ekinci, Assistant Professor of International Relations, Turkish National Police Academy. He received his PhD in Politics from SOAS, University of London. He also conducts research on Ottoman-Turkish music and plays the kanun. He is the author of Kevșerî Mecmûast: 18. Yüzyll Saz Müziği Külliyatı [Kevserî Mecmûast: A Corpus of Eighteenth-Century Instrumental Music] (İstanbul: Pan, 2016). 
Walter Zev Feldman, Visiting Professor of Music, NYU Abu Dhabi. He has conducted research into Ottoman Turkish and Jewish music and is a performer of klezmer and Ottoman traditions. He is author of Music of the Ottoman Court: Makam, Composition, and the Early Ottoman Instrumental Repertoire (Berlin, 1996), and he contributed to New Grove Dictionary of Music and Musicians (2001). In 2004 he co-directed the successful application of the Mevlevi Dervishes of Turkey as a Masterpiece of the Oral and Intangible Heritage of Humanity for UNESCO. His current research interests include the relation of rhythmic cycle (usul) and melody in Ottoman music.

Rachel Harris, Reader in the Music of China and Central Asia, SOAS, University of London. Rachel teaches ethnomusicology and music of China and Central Asia at SOAS, University of London. Her research interests include global musical flows and soundscapes, identity politics, gender and ritual practice. She is the author of two books on musical life in China's Xinjiang Uyghur Autonomous Region and co-editor of three books. She currently leads an AHRC Research Network and the Leverhulme Research Project "Sounding Islam in China", and works on outreach projects relating to Central Asian and Chinese music, including recordings, musical performance and consultancy.

Scheherazade Hassan is an Iraqi Ethnomusicologist who specializes in the music of Iraq and the Arab world. She was an assistant professor at the University of Baghdad, where she founded and directed the first Centre for Traditional Music and conducted extensive fieldwork around Iraq. She taught at the University of Paris-Nanterre and was a visiting scholar at Columbia University Middle East Research Centre in Amman. Currently she is a research associate at the Centre de recherche en Ethnomusicologie at CNRS and a research associate at SOAS. She chairs the ICTM Study Group for the Music of the Arab World. She has published books, recordings and articles in Arabic, English and French.

Eleni Kallimopoulou, Assistant Professor in Ethnomusicology, University of Macedonia. She obtained her PhD from SOAS, supervised by Owen Wright, in 2006. She is author of Paradosiaká: Music, Meaning and Identity in Modern Greece (Ashgate), co-author of Learning Culture through City Soundscapes A Teacher Handbook (University of Macedonia), and co-editor of Introduction in Ethnomusicology (Asini). She has served as reviews editor for Ethnomusicology Forum and her research interests include musical performance and ethnography; public folklore and the politics of culture; nationalism, religion and ritual; oral history; and auditory culture and urban space in Greece and the Mediterranean.

Eckhard Neubauer, Emeritus Professor, Institut für Geschichte der ArabischIslamischen Wissenschaften, Frankfurt am Main. Author of Musiker am Hof der Frühen "Abbasiden” (1965); Arabische Musiktheorie von den Anfängen bis zum 6./12. Jahrhundert (1998); Der Essai sur la musique orientale von Charles Fonton mit Zeichnungen von Adanson (1999); with Elsbeth Ida Neubauer, Arab Music in Western Research: A Bibliography of Books and 


\section{xviii Contributors}

Articles written in Western Languages on the Music of the Arab Countries, Part 1 (2012), Part II (2016).

John O'Connell, Reader in Ethnomusicology, Cardiff University. A graduate of Oxford University, Guildhall, and UCLA where he completed his PhD in ethnomusicology on Turkish music, he has taught ethnomusicology at Otago University and the University of Limerick, having held visiting positions at Queen's University of Belfast and Brown University, among others. His publications principally concern the musical traditions of the Muslim world. He is the principal editor of Music and Conflict (2010) and of many articles on Middle Eastern and Central Asian topics. He has recently completed a monograph on style in Turkish music (SOAS Musicology Series, 2013) and is currently writing a book on music and war in the Middle East.

Jacob Olley, Research Associate, Westfälische Wilhelms-Universität Münster. He works on the digital publication project 'Corpus Musicae Ottomanicae: Critical Editions of Near Eastern Music Manuscripts', funded by the German Research Foundation (DFG). He recently completed a PhD at King's College London on the history of Hampartsum notation. His current research interests include the social and cultural history of music in the Ottoman Empire (eighteenth to nineteenth centuries), the Armenian community of Istanbul, and global approaches to music history. He is co-editor of Rhythmic Cycles and Structures in the Art Music of the Middle East (2017).

Panagiotis C. Poulos, Lecturer, Department of Turkish and Modern Asian Studies, National and Kapodistrian University of Athens. He obtained his $\mathrm{PhD}$ from SOAS in 2006, supervised by Owen Wright. Research interests include the cultural study of music and arts in the late Ottoman period and modern Turkey; history of sound of Ottoman cities; genealogical lineages of musicians and oral transmission; Ottoman musical heritage and politics of culture in modern Turkey. He is co-editor of Ottoman Intimacies, Balkan Musical Realities (2013) and author of Music in the Islamic World: Sources, Perspective, Practices (2015).

George Sawa, independent scholar. Studied voice, theory, and qanun at the Higher Institute of Arabic Music in Egypt. Studied ethnomusicology at the University of Toronto and obtained his doctorate in historical Arabic musicology at the Department of Middle Eastern Studies. He has taught the music of the Middle East at York University, and the University of Toronto (1982-1995), and held the Noor Visiting Professorship at York University (2006-2007). He is the author of five books and 50 articles on Arabic music history and has given numerous concerts in Europe, North America and the Middle East.

Katherine Butler Schofield, Senior Lecturer in Music, Kings College London. A cultural historian and ethnomusicologist whose work focuses on South Asia and the Indian Ocean, she trained as a viola player before embarking on postgraduate studies at SOAS, University of London, in North Indian music, 
followed by a research fellowship at Corpus Christi College, Cambridge, and a lectureship at Leeds. Her research interests include South Asian music, the history of Mughal India (1526-1858), music and Islam and music and empire. They include the intersection of music with gender, friendship, love and ethics; the history of pleasure; colonial transitions; connoisseurship; social liminality; the history of North Indian musicians, dancers and actors; and Indo-Persian musical knowledge.

Martin Stokes, King Edward Professor of Music at King's College London. He has taught ethnomusicology at Queen's University Belfast, the University of Chicago and Oxford. He is the author of The Arabesk Debate: Music and Musicians in Modern Turkey (1992) and The Republic of Love: Cultural Intimacy and Turkish Popular Music (2010). His edited volumes include Ethnicity, Identity and Music (1994) and (with Karin Van Nieuwkerk and Mark LeVine) Islam and Popular Culture (2015).

Ameneh Youssefzadeh received her PhD in ethnomusicology at Nanterre University, Paris, in 1997. Her dissertation was a monograph on the bards of Khorasan, Iran. She has been a visiting scholar at Columbia University and then at the City University of New York. She is currently the Co-Consulting Editor for Musicology of the Encyclopedia Iranica and is collaborating on a project with Professor Stephen Blum. Her areas of study include musical repertoire of the various ethnic groups of Khorasan; music in post-revolutionary Iran and gender. Her publications include several articles, CDs and a book, Les bardes $d u$ Khorassan iranien: le bakhshi et son repertoire (Paris, Peeters, 2002; Persian edition, Tehran: Mahur, 2010). 


\title{
5 Giambattista Toderini and the "Musica Turchesca"
}

\author{
Giovanni De Zorzi
}

Giambattista Toderini (Venice, 1728-1799) was a Jesuit abbot who arrived in Constantinople in October 1781, following a busy career as a scholar and teacher, to join the following of Venetian ambassador (bailo) Agostino Garzoni and his wife Pisana Quirini Stampalia, as theologian and tutor for their son. Here he stayed as he writes in the Introduction of his Letteratura - between October 1781 and May 1786, living in Garzoni's house. In the first months of his stay he began to use his free time with some absent-minded research that followed his earlier interests. Yet, little by little the idea came to life of writing a history of the print works in Constantinople, with a survey of all the existing published books. This idea enlarged and led him to the decision to study the whole of Turkish literature and to an investigation throughout the main archives and libraries of Constantinople that would take form in the huge essay Letteratura Turchesca ("Turkish Literature") published in Venice in three tomes by Giacomo Storti in 1787, just one year after his return. Through the centuries this work gave him universal fame and became a point of reference for Ottoman studies. It also provides a source for Ottoman music studies; the reason for musicological interest is the long Chapter 16 (30 pages and two engravings) that concludes the first volume of the work, entitled, simply, Musica ("Music") and entirely dedicated to Ottoman music. This is the topic of this chapter and, in its first English translation, a gift for Owen Wright.

If his last work is well known, the same cannot be said about Toderini's life and the rest of his publications, so it is worth briefly remembering here the life and work of a world-renowned scholar. A thin biography of the author can be reconstructed, mostly thanks to the works of his Jesuit brethren. ${ }^{1}$ Born in Venice on 27 June 1728, to Domenico Maria Toderini and Anna Maria Cestari, he entered the Jesuit order at the age of 20 (al quarto lustro) and after a formative period he taught philosophy in Verona and Forlì. According to French scholar de Lalande, in 1765 he was in Verona working as an antiquarian, collecting old medals of Gothic kings. ${ }^{2}$

The scarcity of biographical information is redeemed by his consistent work: his most famous Letteratura Turchesca was preceded by a long series of essays on various topics, all far from Ottoman themes, as Dissertazione sopra un legno 


\section{Giovanni De Zorzi}

fossile, che tutto sciogliesi in cenere rossa, Dissertazione sull'induramento di molti bachi da seta, Dissertazione sull'aurora boreale ("Dissertation on a Fossil Woods that Enirely Dissolves in Red Ash", "On the Hardening of Many Silkworms", "On the Aurora Borealis") published in 1770; Filosofia frankliniana delle punte preservatrici dal fulmine, particolarmente applicata alle polveriere, alle navi, e a Santa Barbara in mare ("Franklin's Philosophy Concerning Lightening Rods, Particularly as Applied to Powder-Magazines, to Shops and to Saint Barbara over the Sea"), published in 1771; Dissertazione sopra la Costantiniana apparizione della croce: in hoc signo vince contro al protestante G. Alberto Fabricio ("Dissertation on the Constantine Apparition of the Cross: against the Protestant G. Alberto Fabricio"), published in 1773; Orazione recitata nel di delle solenni esequie celebrate nella veneranda scuola di San Rocco al serenissimo Alvise IV Mocenigo doge di Venice ("Oration Recited on the Day of the Solemn Exequies for Alvise IV Mocenigo, Doge of Venice"), published in 1773.

In L'onesto uomo ovvero saggi di morale filosofia dai principii della ragione ("The Honest Man or Essays in Moral Philosophy from the Principles of Reason"), published in 1781, Toderini exposes his position - typical of a cultivated and up-to-date man - of moderate hostility (given his background) to French Illuminisme. On the authority of the Greek and Latin Classics, he severely criticizes the spiriti libertini ("libertine spirits") of Bayle, Helvetius, d'Alembert, whom he accused of undermining the foundations of the State with their irreligious ideas. Yet his position is not completely conservative and Toderini adopts a more moderate approach to some questions, such as his complete disapproval of torture. In view of his knowledge of French and his literary production in this language, together with his reputation as man of balanced judgement, the Republic of Venice gave him the appointment of censor, a task he accomplished with severity, except for some curious oversights, such as the permission granted to publish Voltaire's Candide and L'ingenu. ${ }^{3}$

While he was in Constantinople, already attending to his Letteratura, Toderini wrote three dissertations: Nuove osservazioni sopra il camaleonte di Smirne, Sull'andamento dei quadrupedi e Dissertazione epistolare sopra due antichissimi Alcorani e alcune monete cufiche ("New Observations Concerning the Chameleon of Smyrna", "On the Manner of Walking of the Quadrupeds" and "Epistolary Dissertation on Two Very Old Qur'ans and some Kufic Coins"). ${ }^{4}$ It is of a certain biographical importance to note here that he dedicated this last dissertation - this time a study on an Oriental and Islamic topic - to the erudite Cardinal Stefano Borgia (1731-1804). This is of interest because we find the same Cardinal as a central actor in the only anecdote we possess on Toderini's life, related by his Jesuit brother Giannantonio Moschini (1773-1840). This episode took place when Toderini had already returned to Venice from Constantinople:

This valorous wearer-of-purple (i.e. Cardinal Borgia) was in Venice for the conclave and, among many other lovers of science and letters, our abbot 
Toderini was presented to him. He introduced himself as the author of the Letteratura Turchesca and was answered, "Bravo! Bravo!". But the cardinal did not stop here and asked him if he knew the Turkish language perfectly; having understood that he did not have any idea, he replied to Toderini: "Oh, a thousand times bravo, to know how to write the history of the literature of a nation, not knowing its language, and to decide on the authors, not knowing their idiom." $"$

Modern readers' sensibilities may require some comment on this anecdote. At that time, a scholar in the entourage of an ambassador, as Toderini served in the entourage of bailo Garzoni, did not serve as an expert Orientalist in the modern linguistic sense. Apart from the fact that Orientalism at that time was in its infancy, what was valued was rather the figure of a curious and intelligent man, i.e. capable of intelligerre ("to find, to connect") in the etymological Latin sense. As we will see, an ambassadorial milieu, with its contacts among the dragomans ${ }^{6}$ and the Ottoman intellectual elite, proved essential for the research of any European author. Venetian and, later, European scholars relied on a network of contacts that, in the old-fashioned anthropologist's jargon, could be defined as "informants". From this point of view we may agree with Cardinal Borgia: bravo! Toderini proved to be an intelligent man who served, as best he could, the Republic of Venice and the world of scholars. Be that as it may, after his return to Venice and the publication of the Letteratura Turchesca, Toderini closed the writing phase of his life and he passed away in July 1799 in the Santi Apostoli parish, near the Jesuit convent of Venice. ${ }^{7}$

\section{The Venetian context}

The Letteratura Turchesca has to be considered in the wider context of relations between Venice and Constantinople. Putting aside their close mutual relations in the Byzantine epoch, in the "new" Constantinople conquered by the Ottomans existed already from the fifteenth century a so-called casa bailaggia ("home of the bailo") that the Venetians, by permission of Sultan Mehmed II "Fatih", received from a merchant community from Ancona. Later, in the sixteenth century, the Venetian community moved to a part of Galata called "Pera", preferred for the "more salubrious air". ${ }^{8}$ Here they began by renting a house from a family that furnished them with interpreters. Subsequently, they bought and restored a house in Tomtom Sokak, which became what is nowadays the Italian consulate in Turkey. Thanks to this privileged vantage point, Venetian knowledge of the Ottoman world was more accurate compared to the rest of Europe, if only for the written accounts ${ }^{9}$ that Venetian ambassadors were obliged to give to the Senate at the end of their tenure. In general, such relations dealt almost exclusively with politics, diplomacy and war strategies, but with time a genuine interest in Ottoman culture developed in Venice, one that produced works such as Gl'Annali Turcheschi ("The Turkish annals") by Francesco Sansovino (1573), dedicated to 


\section{Giovanni De Zorzi}

the Sultans and their histories, the milestone Della letteratura de Turchi ("On the Literature of the Turks") by bailo Giovan Battista Donado (1688) and finally our Letteratura Turchesca.

Despite the existing net of dragomans and translators, over time the formation of an original Venetian school of young interpreters became an important issue. This was a central theme under bailo Giovan Battista Donado (1627-1699), who encouraged the birth of a school of young interpreters called giovani di lingua and who himself studied Turkish language with Venetian-Armenian Giovanni Agop (1635-1691), author of one of the first Turkish grammars. ${ }^{10}$ From the Donado entourage we should remember the names of dragoman Gian Rinaldo Carli $(1646-1720)^{11}$ and of the young Antonio Benetti (c.1640-1685), who wrote an interesting three-volume book on his sojourn in Constantinople in the following of bailo Donado. ${ }^{12}$ The four giovani di lingua (Benetti with Francesco Flangini, Stefano Fortis and Antonio Paoluzzi) produced a collective book of translations from the Ottoman ${ }^{13}$ and it is noteworthy that all these works were published at the end of Donado's tenure, like a kind of manifesto, in the same year of 1688 and under the same Venetian publisher, Andrea Poletti.

Compared to a powerful ambassador like Donado, Toderini was a single scholar who could not rely on an entourage of men of letters dealing with Ottoman themes. Yet, as he states in his Introduction, bailo Agostino Garzoni provided him with connections in the Ottoman government and among Ottoman intellectuals. Thanks to his character, to the passion that animated his research, and maybe to his position as abbot, somehow similar to an Islamic scholarcleric, Toderini became friends with ulema and muftis; he received their advice (even a fetve) and was granted access to the main libraries in Constantinople and in the Seraglio. On strictly linguistic matters, he dealt mostly with dragoman Giovanni Battista Calavrò Imberti, who was described as "valente nel turco e versato nelle belle lettere latine, ed italiane" ("able in Turkish language and versed in Latin and Italian belles lettres"), and he relied on documents translated into the main European languages, often asking advice from European colleagues and specialists.

In the context of this relationship between Venice and Constantinople, Toderini's main work was sometimes considered a mere "diplomatic move" without circulation, as was certainly the case with Donado's valuable and ground-breaking Della Letteratura. On the contrary, the circulation and good reception of Toderini's main work among the European audience of intellectuals and colleagues (la repubblica dei letterati) of the late eighteenth century seems to be proved by the many reviews that the work received immediately after its publication and by the two translations, into the French and German languages, ${ }^{14}$ that were published in the brief three-year span after its issue. In sum, in the wider context of eighteenth-century curiosity for the turcherie, and a general interest in travel chronicles, the Letteratura Turchesca arrived as a solid point of reference that was more and more appreciated as a first-hand source of information on Ottoman culture. 


\section{European travellers and their observations of Ottoman music}

Even if privileged from the beginning, the Republic of Venice was not the only nation dealing with the Ottoman Empire and having a seat in Constantinople so that, at least from the sixteenth century, there flourished a whole literature based on the observations of foreigner travellers and scholars writing in French and English. Of interest to our particular musical perspective are the observations on the music and musical instruments of a Mevlevî ritual (semâ, âyin, mukabele) made through the centuries by many European travellers and scholars, ${ }^{15}$ such as the musician Pietro della Valle in $1614 ;{ }^{16}$ the short musical transcription of a vocal composition on the verses Hey Ki Hezar Aferyn, also from a Mevlevî rite, that can be read in an account by du Loir; ${ }^{17}$ the observations on Turkish music and musical instruments made by the English writer, John Covel (1670-1679),${ }^{18}$ and the Venetian, Donado, ${ }^{19}$ who appends in the conclusion of his essay some musical transcriptions that would be criticized by Toderini for being based on a Western 12 equal semitone system. We can read another description of a Mevlevî ritual, complete with a transcription made by Sieur Chabert, in Charles de Ferriol (17141715) that Toderini knew (and criticized). ${ }^{20}$ In 1716 the famous Gabinetto armonico pieno d'Instromenti by Filippo Bonanni was published, in which we find a description and tables of Ottoman instruments: a first essay in modern organology. Toderini did not know of a long and detailed article written in 1751 in Constantinople by the young French jeune de langue Charles Fonton (1725-1793), with illustrations made by his friend Jean-Baptiste Adanson (1732-1803). He also did not seem to know the observations on music at the Seraglio, in their Italian translation published in 1679, made by music-pageboy Wojciech 'Ali Ufkî Bobowski (1610-c.1675), better known to Western scholars by his Latinized name Albertus Bobovius Leopolitanus. ${ }^{21}$

\section{Toderini's chapter on music}

Chapter 16 Musica (30 pages, from 222 to 252, with two engravings) concludes the first volume of the Letteratura Turchesca. In it, Toderini deals with many topics that I will not comment on in view of space limits, preferring to present here the full text and leave the field open to other scholars. Its themes include Ottoman music history, which is traced following Cantemir; its theories as they relate to Arab-Persian musicology; alphabetical Greek and Arab/Persian notation; description of musical instruments; the division of the octave into 24 unequal microtones, and ending with epistolary exchanges with his Jesuit brethren Abbott Pizzati (1732-1803) and Abbott Juan Andrés (1740-1817). The chapter concludes with two engravings that became very famous: the first of a long-necked lute tanburr, with its fretting and its immanent musical system, and the second of a piece called Concerto Turco Nominato Izia Semaisi ${ }^{22}$ which is the well-known Hicaz Son Yürük Semâ 'î that concludes at least three Mevlevî ayyin. ${ }^{23}$ 


\section{Giovanni De Zorzi}

The chapter, written in a rather antiquated Italian and with an obsolete syntax and punctuation, is nevertheless perfectly readable. I have maintained Toderini's transliteration of Arab, Persian and Ottoman terms and names. All over the chapter, the author marks his footnotes with a Latin letter in italics, abbreviating the source in the footnote: I have restored these abbreviations for the sake of the reader.

\section{Chapter XVI}

\section{Music}

The Turks of Constantinople lived without the art, or the science, of music until Amurat IV in 1047 of Hegira. The cruel conqueror ordered that 30,000 Persians be murdered under his eyes. When the most part of the slaughter was finished, Schah Culì, the Orpheus of Persia, found a way to present himself to the fiery Sultan, singing on the harp the tragic Baghdad massacre and the triumph of the victorious, with an enthusiasm excited by the most passionate nature. The concert was so plaintive and wonderful that the hard heart of that barbarous sweetened, and he could not refrain from tears of compassion. The slaughter was suspended and the excellent player saved the life of an immense population. Amurat took him to Constantinople with four other players and they established among the Turks the sweetest science of music $(a){ }^{24}$

Under Mahomet IV, writes Cantimir (b), ${ }^{25}$ we saw [Music] not only revive but arrive at its perfection by wonderful virtue of Osman Efendi, who trained many instrumentalists and singers. Among the players flourished with a great name in Constantinople, Dervisch Othman and his disciple Curuschunij Ogli, and two Greeks who taught this art to Cantimir. Among the singers, this metropolis counts four of the most illustrious Muslims. I observe, nevertheless, that before this epoch among the Turks lived with great fame Mustafà Tchengnì $(a){ }^{26}$

From 1691 of the Christian era, the learned prince Cantimir dedicated himself to learning Turkish music on instruments, deeply studying its difficult theory. Then, at the request of Daul Ismael Efendi, treasurer of the Empire, and Latif Ktelebi, treasurer of the Seraglio, both experts in this art and great music lovers, he composed a scientific treatise on the art of music in Turkish language, and dedicated it to Sultan Acmet II. This treatise, even if he writes $(b)^{27}$ ' $j$ 'apprends qu'on s'en sert par-tout pour apprendre cet $a r t$ ", is nowadays extremely rare. Nevertheless I found the Cantimir manuscript in the Turkish language, without introduction or dedication, entitled Tarifu ilmil-musiki ala veghi machus or "Explanation of Music in a More Detailed Way".

To Cantimir the Turks owe musical notation, which he firstly applied when composing a rare book of Turkish melodies (original: arie turchesche). 
These are listened to with pleasure even nowadays and are called Cantimir's airs. After long and diligent research, I found a copy: I saw the notations, which consist of Turkish letters and numbers, like the alphabet letters that were in use by ancient Greeks $(a)^{28}$ and by the Romans and Italians, before Benedictine Guido d'Arezzo found the points ${ }^{29}$ and, after 300 years, Giovanni Maria Parigino developed the musical notation that we use in the present day.

But finding the theory too difficult, the Turks put aside musical notation and returned to composing and playing everything by memory, as in the past.

Turkish music is based on solid principles and rules, so that it can really be defined as theoretical. Cantimir's work is based upon such principles, as well as upon the Arab and Persian treatises that deal with the argument; the same Turkish Airs of Cantimir (original: Arie Turchesche del Cantimir) were composed according to these rules ${ }^{30}$ Turkish music was written with European notes in proper time and measure in the old book Letteratura de' Turchi ${ }^{31}$ and in the book of Ambassador Ferriol (a) ${ }^{32}$ as some connoisseurs showed me after I had posed many questions and made many requests. Finally, the essay on Turkish music is based on rules and principles that the reader can see at the end of the present chapter, which I was asked to prepare, and realized with great study and difficulty with European musical notation. In brief, the Turkish have all the tempos and tones (original: tutti li tempi e li tuoni) as well as all the intonations that we have, but they are richer in semitones and in melody.

Playing music without scores, as is done among the Turks, does not mean to be without principles and musical rules; the second proposition does not derive from the first. The Arabs, as the Persians, completely lack musical notation and yet they invented rules and studied with doctrine the science that they called Ilmi Musiki, which means "Science of Music". There are in Constantinople some of the best masters who in order to compose music use some signs and notes a capriccio $^{33}$ but always in the same way, to help the memory. So we cannot agree with the letter n. 38 of M. Guis, in which he tries to prove that the Turkish lack a theory of music $(a) .{ }^{34}$

Turkish music comprehends the 12 semitones, like our music, but they know how to divide them in smaller parts on the instruments, as we will see, so that Turkish music abounds in melody ${ }^{35}$ For this reason it is no wonder if the Turks, with ears accustomed to such melodious sounds (original: melodici concenti), do not delight themselves in European music, which they consider less melodious, even if consonant and harmonious.

The majority of upper-class and noble Turks take pleasure in music, which, as was among the Greeks, is a part of their whole system of education and culture. Niebuhr's claim - that Turks of high social condition think that they would lose honour if they learn music - is false $(a) \cdot{ }^{36}$ In his Republic, Plato recommended that the young study the science of music for three years. The Turks study and practice music for a long time, moreover 
on string instruments and on the Neì. They keep male and female slaves who can play for their delectation. Yet, the lords do not want to be heard in public, unless playing the Neì among friends, because this is considered as an instrument of study ${ }^{37}$ This I learned from Ibraimo Efendi in the meadows of Bojux-derè, ${ }^{38}$ when an Ulemà friend of mine played for me together with the best Dervis Mevlevì, who came that day in order to make me listen to the sweetest sound of that instrument.

Mr. Guer $(a)^{39}$ wrote that the Seraglio infirmary resonates with music and voices from dawn to dusk, in order to cheer the melancholic and sad souls of the patients. The same error was reported in a recent Italian pamphlet. This is false, as many, above all Mr. Gobis, 20 years physician of the Seraglio, confirmed to me.

Many pageboys learn music and often they pretend to be sick in order to benefit from the freedom that the Infirmary allows them. In fact, this is remote from the inner part of the Seraglio, so that they can communicate more easily with the persons from outside: they make them call and then they drink wine together, indulging in excess. For exercise, or for pleasure, they often make music for hours on end; it is for this reason that music and singing can be heard in the Infirmary, and from this derives the error of the above-mentioned writers.

The music cultivated today by Greeks in Constantinople, except for the liturgical chant, which shows art, and the romeca, which is not of much interest, is entirely Turkish music. On the basis of this they adapt Greek songs that they notate with their horizontal, oblique, curved, half-circled and elliptical lines, with squared and round points, and other similar signs.

In Chalcedon I was looking for music books in the Greek church of Saint Euphemia: we will not write here that this is the church where the Council was held ${ }^{40}$ as did Niebuhr $(a)^{41}$ and Grelot $(b),{ }^{42}$ but in another one, not so far, more antique and more ruined, where there is an agiasma, or a source of baptismal water. The parson of the church, by tradition, believed that this was the real site of the Council, as we can find in Evagrio Scolastico (English: Evagrius Scholasticus), among the Gillio $(c),{ }^{43}$ the Turnefort $(d)^{44}$ and the Spond $(e),{ }^{45}$ who mention a marble inscription in which the Council was quoted.

After many talks the Parson showed me a little book with a few pages in Greek musical notation, and gave it to me as a present, which I conserve among my manuscripts.

Turkish music, as we saw, is Persian modern. In fact, under the reign of Cosroe Parviz, ${ }^{46}$ in the time of Emperor Heraclius and Mohammed, music flourished among the Persians. Barbud, ${ }^{47}$ who lived at the court of that king, was considered the Orpheus of the Persia. In those days, on the contrary, the Arabs were uncouth in science, being good only at poetry, for the perfection and elegance of their tongue is evident in the Koran and in the early Arab poets. So it seems very probable to me that the Arab Muslims 
learned this practice from the Persians. In fact the Soavi $(a)^{48}$ writes that the Arabs learned music from the Persians, taking from them many musical terms.

When the arts and the sciences were finally taken and cultivated by the Arabs, many Arab authors who wrote on music flourished. This science was treated not only according to the mathematical sciences, but also according to the rules of musical taste in singing and playing. Many Arab authors are quoted by Hagi Calfah, ${ }^{49}$ by Herbelot and by Casiri $(a)^{50}$ and many treatises can be found in the Constantinopolitan libraries of Atif, Sultan Osman and Raghib Pascià, as the Muderìs of the Validè told me. ${ }^{51}$ In the Index of the Seraglio Library I found the book entitled Introduction to Music by Kadaji. The work Medchalul Musiki Farabi, or Introduction to Music by Alfarabio, passed away in 343 of the Hegira, is in the catalogue of the Sultan Abullhamid library; yet, after meticulous and repeated searches, we could not find the text. The Farabian manuscript called Elements of Music, present at the Escurial, as Casiri writes $(a)^{52}$ deals with the principles of the art, with the composition of the voices and musical notation of the Arabs, completed by more than 30 illustrations of musical instruments.

I wrote to the very erudite Abbot Andres ${ }^{53}$ that in my opinion these illustrations were made in later times, after Farabì, and that the musical notation could not be considered similar to ours, neither in power nor in function, because no Muslim book on music was ever seen with such signs.

The Abbott kindly answered me that the codex was not the original manuscript nor contemporary to Farabì, and sent me the musical notations, which are rather signs indicating sound proportions, as we can see in Persian and Turkish treatises: we will come back to this argument later, because at the end of our chapter we will report his erudite letter in its entirety.

The Arabs do not lack treatises on musical instruments, quoted by Hagì Calfah, by Herbelot and Casiri $(a) \cdot{ }^{54}$ Yet, among the Arabs, art music ${ }^{55}$ fell in a state of decline many years ago, while Persians, who wrote many treatises on this topic, always cultivated it. Among these authors, we would like to remember Abù Aluja Ibn Sahid, who deals with singing and instruments, distinguishing between wind instruments and plucked instruments (original: stromenti da fiato e da tasto). ${ }^{56}$ The Chevalier Chardin ${ }^{57}$ took the codex to Europe together with other treatises. From this author, he gave us some geometrical figures that surely deal with musical art. ${ }^{58}$

Mr. Akerblad, ${ }^{59}$ a Swedish traveller very good in Oriental languages, told me that he saw in Constantinople a Turkish music treatise with circles and other geometrical figures, entitled Edvarì Musiki (Circles of Music). These are the musical notations we find in Arab, Persian and Turkish books, as I also learned from the Muderìs of the Valide. 


\section{Giovanni De Zorzi}

\section{On the musical instruments played by the Turks}

In order to complete this chapter, I present to the reader some information on the musical instruments played by Turks and an essay on their music - to the best of my ability - in Western notation.

Chamber music instruments

1. Keman, a violin like ours.

2. Ajaklì Keman, a type of a violin with a foot that is played like our bass.

3. Sinè Keman, a viola d'amore.

4. Rebab, a two-stringed bowed instrument, round as a sphere, with a small hole in the convex part, but for some years not much used by the Turks.

5. Tambur, an eight-stringed instrument, seven in steel and one in copper, with a very long neck. The setting of the pitches is on the frets. ${ }^{60}$ As I saw many times, it is played with a thin flexible plate of tortoise shell. ${ }^{61}$ There is no hole.

6. Neì, a type of a transverse flute of reed. It can produce a thin sound similar to the German flute, or a sound similar to the human voice.

7. Ghirif, a sort of smaller nei which does not produce a low voice like the bigger one.

8. There is also the nei piccolo, which is not used in performance.

9. Mescal, an instrument with many unequal reeds that plays many octaves, like the rustic panpipes. The Turkish version has up to twenty-three reeds and each can produce three different sounds, according to the blowing technique.

10. Santur, or psaltery, similar to ours, with metal strings which are hit with little rods.

11. Canun, a sort of psaltery with strings of sheep or cow gut. It is played by women in the Seraglio with tortoise-shell thimbles that have a piece of coconut on the point.

12. Dairè, a large circular [drum] three inches [in diameter] with the skin on one side only; thanks to small metal bars, a pair of small round brass plates are fixed in five places ${ }^{62}$ that accompany the main percussive sound with their tinkling sound. The Dairè is used to mark the beat.

Mecter hanè, military music instruments

1. Zurnà, similar in its form and its sound to the oboe.

2. Kabà Zurnà, the same, but larger, with a baritone voice.

3. Borù, a type of small brass trumpet. 
4. Zil, Moorish instrument. Two round brass plates with a small hemispherical cavity in the middle. On the convex side there are two handles to hold and beat the two plates against each other.

5. Daul, a larger than the ordinary drum, with a wooden resonating box. It is played with a large stick in one hand and a thinner one in the other, following the tempo of the piece. ${ }^{63}$

6. Tombelek, or Naarà, a type of small wooden kettledrums; the diameter is little more than half a foot.

7. Kios, large copper kettledrums that are commonly placed on camels.

The supreme Vizier, and the Pashas, as well as the Captain Pasha, or the great Admiral of the fleet, all have a band of military instruments with many players. The princes of Wallachia and Moldavia have the same in their courts. The royal band of the Constantinople Sultan, composed of Turkish musicians, is grandiose; it plays during the two Bairam, for the Donalmà, ${ }^{64}$ at the feasts for the birth of the sultanas, on other occasions for rejoicing, and at the Sultan's will. All play in unison: some play the higher octave and others play the lower octave, because this is the nature of Turkish music.

In the Seraglio there is a numerous company of chamber musicians for the Sultan, which consists only of Turks. They play music for the Emperor's delight several times a week. Outside the Seraglio live some of the best musicians who can be found in Constantinople: Greeks, Armenians, Turks and Jews. The Greek, Anastasio, and the Armenian, Rafael, are highly renowned for their excellence in music and on the violin: Rafael is very cultivated and plays the tambur impressively, but the two Turks play wonderfully this instrument. Some dervishes from the Tekies play the nei with great art; the instrument is very cultivated and appreciated by them.

After much research, I found the famous Sach culi ${ }^{65}$ sonata, which saved the life of many Persians: it is nowadays conserved by tradition and is played by the best masters in Constantinople. The Pescerfi Bagdati Fetichi, or "Sonata on the taking of Baghdad", is nowadays called "Muselic", as I learned from the erudite player Rafael Armeno; he sweetly played for me on the string instrument called tambur. It seemed to me capable of entering straight to the heart, and gave me a wonderful delight: I consider the Sonata as the most illustrious monument in all music, well deserving of the entire Humanity. ${ }^{66}$

The Meveli ${ }^{67}$ dervishes, named in this way after their founder, having introduced the dance, as a religious cult, in their Oratorio ${ }^{68}$ (which in no way they would call a mosque) practise a great deal of music, and are among the best musicians. They play wind instruments and kettledrums, as I saw when 


\section{Giovanni De Zorzi}

I was at their swirling dances, where they whirl rapidly like a spinning top. They play the nei finely, not using the top joint of the finger (apart from the little finger), as we do, but using the second extension, the phalanx, of the finger. It is an easy instrument, all open above, of a singular sweetness and similar to the human voice.

The air to which the dervishes dance can be seen in European notation in the illustrious work of the Ambassador de Ferriol $(a){ }^{69}$ yet when it was read and played on the violin by a master, the Turkish listeners didn't recognize it at all, and had a good laugh. In honesty, some pitches cannot be expressed by European notation. It is necessary to create new figures and notations and give them the correct values: this is a thorny matter that needs long meditation and uncommon skill, both in our own as well as in Turkish music.

\section{Essay in Turkish music}

In order to give a clear idea of the character and the theory of Turkish music, it seems convenient to compare it to our European music. The latter is composed of 12 semitones, while the Turkish has 24;12 are the same semitones that we have, while the other 12 are parts of our semitones. Six are larger and six are smaller than our semitone. Thus, Turkish masters divide each European tone into four parts, or grades.

In order to distinguish more clearly, and to perceive the difference between our tones and the Turkish ones, I present the scales here in Table I, which was prepared and realized with much art by a good master of European music, with a certain knowledge of Turkish music, helped by two good musicians of Ottoman music. The sign of an "O" cross-cut denotes a tone smaller or larger than a sharp: smaller if it is before the sharp, larger if it is after the sharp. We have always to remember that Turks divide a single European tone in four parts. None of the notes marked with the sign " $X$ " are used in our music, but are necessary in Turkish music, which is very rich in melody, though lacking in harmony, being played only in unison.

Not all the Turkish musical instruments are capable of such a division. Some of them are lacking in some parts, as the tambur that we can see in Table I, an instrument with a very long neck, provided with eight metallic strings: its division is depicted in the Table with its alterations, sharps, flats and naturals with the sign "O" cross-cut, that we have already described above. Yet, the instrument contains all the tones necessary for all its intonations. Playing the viola d'amore, they use these semitones ${ }^{70}$ in all the octaves.

Now, let us see Table I and II, which present to the reader a new endeavour, an attempt to express Turkish music in our European notation, approved 
เั
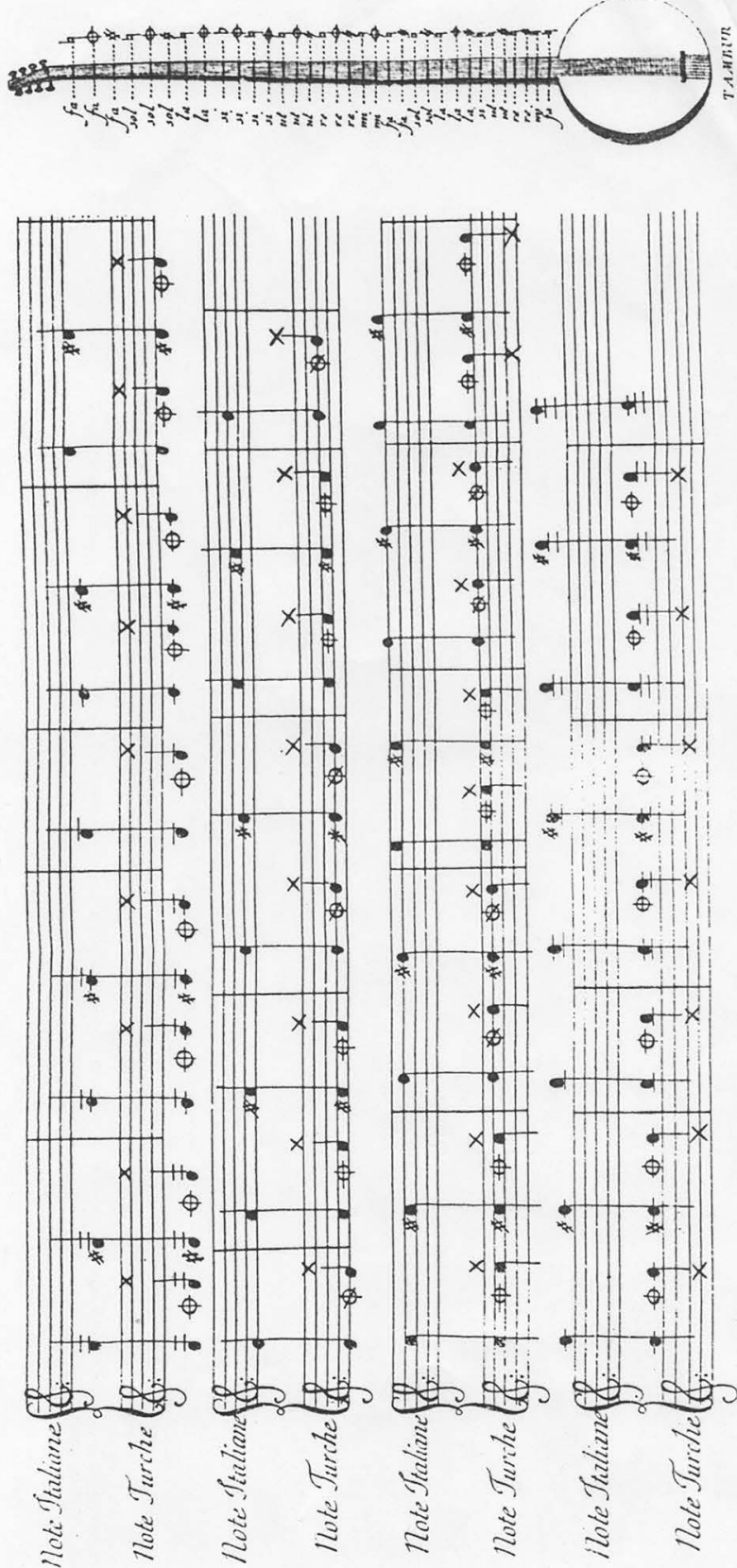

D 
Review Copy - Not for Distribution

Giovanni DE ZORZI - University "Ca' Foscari" of Venice - 22/01/2018

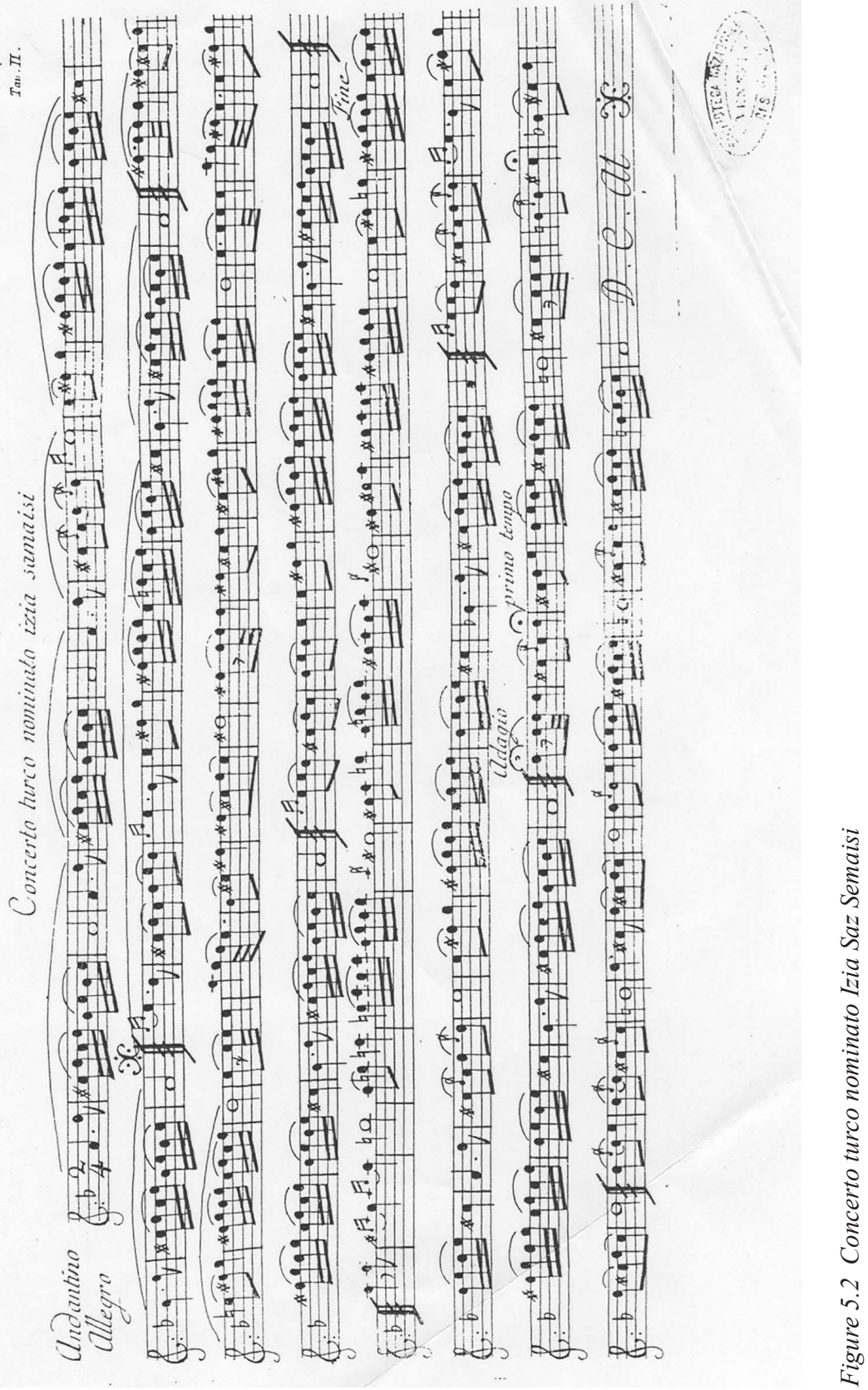


by experts in this music. Even the non-experts, when listening to these Ottoman arias and sonatas, will be capable of perceiving the genius and the spirit of this music, which will not happen if they play from the musical scores arranged by Mr. Ferriol, French Ambassador at the Sublime Door, or in the earlier ones from the Letteratura de' Turchi by Bailo Donado, cited above.

This knowledge may open a new field for the masters, in order to enrich and embellish Italian music, enlightening the scientific theory and the obscure history of music in Greek and Latin authors. The Abbot Pizzati, illustrious in the Literary Republic for his original work entitled "Science of Sounds and Harmony" ${ }^{71}$ is highly appreciated by the illustrious father Martini, who asked for the portrait of the author and put it in his gallery among the great scientific writers on music. When he saw the present chapter, he wrote to me what follows in a friendly letter, after the usual greetings, honouring my little work.

"I have read the exact and diligent exposition that You have made of the musical scale of the Turks. And this proves the not-so-small errors committed by those who believe that only the musical intervals that we have in our diatonic scale are necessary for musical practice; as if such practice should depend only on our division of the scale, and as if a better one should not exist. There is no doubt that the diatonic musical scale of the Turks, as we can see in Your work, is more complete than ours, because it is richer in voices, ${ }^{72}$ compared to our division, the Turks dividing the tone into more parts; from this, we can see that their melodies are without doubt more varied and graceful.

"As far as I have observed, among their musical intervals the Turks have an interval which corresponds to the Seventh, and that consists of a ratio of 1:7, or 9:15 3/4. In my work I call this interval the 'Harmonic Seventh'; it is different from our usual Seventh that consists of the ratio 9:16. The first is without doubt better than the second: the same resonance of the stretched string manifests and suggests such an interval. If only we had that interval, we could go with ease to the higher octave of a given tonic in our scale, thanks to the harmonies of the fundamental strings of a tone, or musical mode, as I showed in my work. The Turks should do the same, if their music was not limited, as You teach us, to melody alone, as was Greek music. According to the opinion of many, it is capable, due to this characteristic, of entering the soul and producing the effects narrated by many stories. Putting aside any question of Greek music, I will only say that where we deal with musical instruments which have stable voices and where it would be impossible to multiply the intervals of our usual diatonic scale, still it would be good and desirable that our professors would study and practise a larger number of intervals than we 


\section{Giovanni De Zorzi}

usually consider in our scales, in order to use them when necessary, as did the famous Tartini. ${ }^{73}$ But commonly in practical matters we follow the easier path, omitting the more perfect." Etc.

Let me report here also the letter that the eminent Abbott Andres wrote me: speaking about the Farabi manuscript, with erudition and learning, he commented on an extract of my work that the immortal Casiri gave him, and his opinion on Arab music can conclude this chapter.

Mantua, 29 March 1785

"I finally had sight of Your very interesting work in the Novelle Letterarie di Firenze. I am delighted, and I congratulate you. If Leibnizio, ${ }^{74}$ among all the works he saw in Venice, held in great esteem the slight and less wellprocessed work of Donado, what would he have said of the vast and erudite work that You are preparing on the same topic? I wish You health and ease in finishing it and publishing it, waiting with impatience. Thank You for the news You are giving me. About the clock of the Arabs (a pendulum-clock), I myself have suggested many books to Casiri, asking him to consult them, but his age did not permit it, and the fact that many manuscripts are at the Escurial, many miles from Madrid, render the thing rather difficult for him. Of the Farabi manuscript, You are right: it is not his own, but a copy that Kamel made from an antique manuscript from Zaragoza from Aben Pace, his master. Here are Casiri's words:

" "Manuscript in Kufic letters found in Cordoba, without a note on the year [of writing], in which we have a work from the most excellent philosopher Abi Nesser Mohamad Ben Mohamad Al Pharabi, whose life we quoted above, entitled Elements of Music and divided in three parts: the first deals with the principles of this art; the second with both vocal and instrumental compositions; the third deals with compositions of various genres, with musical notation and more than 30 figures of musical instruments. This manuscript, among other very ancient ones, (comes) from Cæsaraugusta [today's Tarragona] by the ancient philosopher Abì Baker Ben Alsalegh Ebn Bageh, commonly known as Aben Pace; he described himself as a witness to Abilhassonus Ben Abì Kamel Cordubensis, a student of the same Aben Pace. So it is plausible that the manuscript was written within the year 525 Hegira, because it is said that in the same year Aben Pace passed away. ${ }^{75}$

" 'When I received an extract from this manuscript, I found in it illustrations of 30 musical instruments, and others of musical compositions. The instrument here is the Al-Chaherud, invented in Samarkand by Hakim Ben Ahrias, and we can see illustrations of many other string and wind instruments. The manuscript contains also the Tables of Farabi, where, by lines and letters, he explains the musical capabilities of some instruments. I thought it 


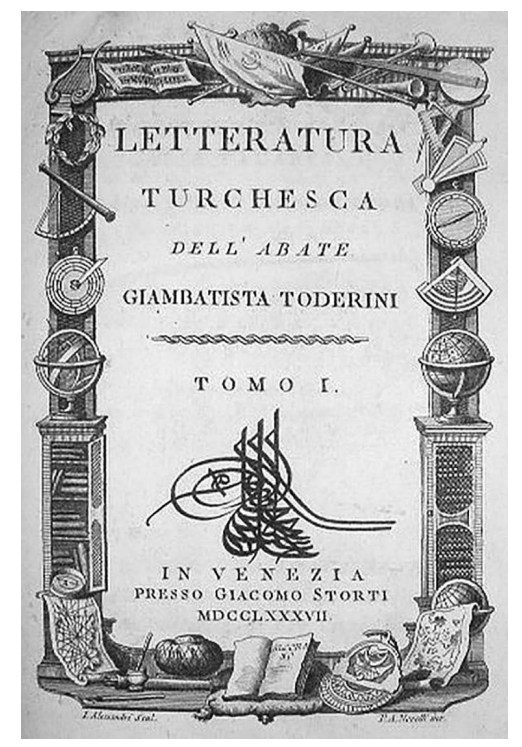

Figure 5.3 Frontispiece of the Letteratura Turchesca with musical instruments and scores

good to make a copy for You, on the enclosed paper, of an instrument called Al-Rabab, and on another the harmony of the voices of 15 strings, on the Fourth, Fifth and Octave and never on the Third. This may shed some light on Greek music for You; moreover, looking at the entire manuscript, realizing how the entire Musical doctrine is taken from the Greeks, I also want to copy the Index of Your work, and send it to Spain: if this produces some news on the points You are dealing with, I will let You know. For the moment You can see that, even if some figures could be later additions, other must be from Farabi, and, in any case, they are used by the Arabs. I have appreciated very much the news You gave me of Mr. de Villoison and the Count de Choiseul Gouffier. If You have any similar news to give me, or other questions to ask me, it will honour me, with esteem, etc."

\section{End of the First Volume}

\section{Notes}

1 Biographical information on Toderini includes, in chronological order: Moschini 1806: pp. 240-241; De Angélis 1829: pp. 456-457; Sommervogel 1890-1900: pp. 58-59. A modern survey can be found in: Preto 1975, pp. 525-528.

2 de Lalande 1786: p. 229.

3 Berengo 1956: p. 204.

4 The three dissertations were later collected and edited by Domenico Maria Toderini (Toderini 1810). 
100 Giovanni De Zorzi

5 Moschini Della Letteratura, vol. II, 241.

6 From Arab tarjumān, derives Turkish tercüman and Italian dragomanno (antiquely also turcimanno): "translator".

7 From this note by Moschini, this author learns that I am not only Toderini's fellow citizen but also his parishioner.

8 Pedani 2010: p. 18.

9 Now collected in Firpo 1984, and in Pedani-Fabris 1996.

10 Agop 1685.

11 See Paladino 1917, and the more recent study by Mario Infelise: "Gian Rinaldo Carli Senior, Dragomanno della Repubblica": www.istrianet.org/istria/illustri/carli/07 acta-abstract.html (accessed 28 October 2014).

12 Benetti 1688.

13 Benetti et al. 1688 .

14 Toderini 1789, 1790. According to Paolo Preto, a Spanish translation made by the Chilean Jesuit Warcisse Vas remained unpublished.

15 Observations transcribed, translated into English and annotated in De Zorzi 2015.

16 Della Valle 1843: pp. 47-50.

17 du Loir 1654: p. 154.

18 Covel 1893: pp. 168-169, 211-216.

19 Donado 1688: p. 131. Musical scores in unnumbered folding pages after p. 140.

20 de Ferriol 1714-1715: p. 26. A text under the score says: "Air sur lequel tournent les Derviches de Pera, noté par le Sieur Chabert qui était avec M. de Ferriol et qui en a composé la Basse."

21 Magni 1679: pp. 550-552.

22 The Concerto has been recorded several times: for example by Concerto Köln with the Ensemble Sarband in Dream of the Orient, Deutsche Grammophon, 2003, CD: 474 193-2. Track 4.

23 In chronological order, the anonymous hicaz son yürük semâî concludes the âyin in maqam beyati composed by Derviş Küçek Mustafa Dede (d. 1683), from Edirne. The same hicaz son yürük semâ̂ concludes the âyin in maqam hicaz composed by Musahip "Vardakosta" Ahmed Ağa (1724-1794) and the âyin in maqam hicaz composed by Abdurrahim Kunhi Dede (1769-1831). Toderini and/or his assistants could have listened to the hicaz son yürük semâl from one of the quoted âyin.

24 (a) Cantemir, Histh. Oth., T. III, p. 101. (Toderini's footnote). T. stands for "tome" (volume). Toderini refers here to the French version: Cantemir 1743.

25 (b) L. c. T. II: p. 235 (Toderini's footnote).

26 (a) Herb. alla voce Mostafà. (Toderini's footnote). Herb. alludes here to Barthélemy d'Herbelot de Molainville (1625-1695) and the entry "Mostafä" from his enormous Bibliothèque orientale, ou Dictionnaire universel contenant tout ce qui fait connoître les peuples de l'Orient (...) (Paris: par la Compagnie des Libraires, 1697). Republished in Maastricht (1776), The Hague (4 vols, 1777-1799) and in Paris (6 vols, 1781-1783) with contributions by Orientalists such as Albert Schultens, Johann Jacob Reiske, Claude de Visdelou and Antoine Galland.

27 Histh. Oth. T II, page 327 (Toderini's footnote). As above, the author refers here to the French version: Cantemir, 1743.

28 Alipii Tabulce (Toderini's footnote). Here the author clearly refers to the Greek

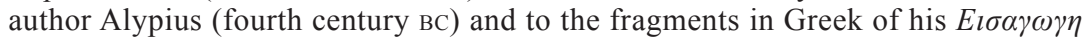

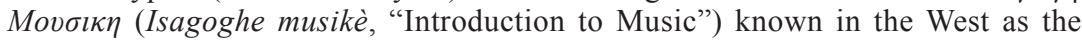
Alipii Tabulce. The manuscript, propriety of Dutch humanist Joseph Justus Scaliger (1540-1609), was translated and published for the first time in Leiden, Meursius, only in 1616. 
29 In original Italian: "ritrovasse i punti". In a rather obscure way, Toderini with "points" alludes here to the symbols of the notes in the musical staff notation.

30 A transcription made by Charles Fonton of a tune entitled Air de Cantemir can be read in Fonton 1989: p. 11.

31 Toderini alludes here to Donado 1688.

32 (a) Recueil des cent estampes, p. 26, à Paris, 1714; (Toderini's footnote). Here and later on Toderini alludes to Ferriol 1714-1715.

33 I leave here the original Italian term a capriccio ("following one's fancy") indicating a free approach to the tempo (and possibly the style) of the piece.

34 (a) Voy. Littér. de la Grèce, T II; (Toderini's footnote). Here the author alludes to Guys 1776.

35 Abbonda di multiplice melodia: literally, "abounds in multiple melody". Toderini seems to refer here to the richness that the "smaller" intervals give to the melos: a monophony with many (multiple) intervals inside the melody.

36 Niebuhr, Voy. En Arabie, T. I. p. 142 (Toderini's footnote). The author alludes here, and below, to Karsten (or Carsten) Niebuhr (1733-1815) and to his Reisebeschreibung von Arabien und anderen umliegenden Ländern, first published in 1772. French and Dutch translations of Niebuhr's narratives were published already during his lifetime; here Toderini very probably indicates his Voyage en Arabie \& en d'autres pays circonvoisins (Niebuhr 1776).

37 In the Italian original, "stromento di studio": it is unclear if Toderini meant by "study" the normal study and practice of a given instrument, or if he alluded to a form of inner practice, typical of the world of ney, and among Mevlevî dervishes.

38 Nowadays Buyük Dere, although the meadows have disappeared.

39 Mœurs et usages des Turcs. T. II. P. 92 (Toderini's footnote). The author alludes here to Guer 1746-1747.

40 Toderini refers here to the famous Council of Chalcedon that took place in $451 \mathrm{AD}$, probably in contemporary Kadiköy, on the Asian side of the Bosphorus.

41 (a) Voy. En Arabie, T. I. p. 26. (Toderini's footnote).

42 (b) Relation d'un Voy. de Constantinop. p. 50 (Toderini's footnote). Here the author alludes to Guillaume Joseph Grelot (c.1630-?) and to his Relation nouvelle d'un voyage de Constantinople. Enrichie de plans levez par l'auteur sur les lieux... (Paris: veuve Damien Foucault/Pierre Rocolet, 1680).

43 (c) De Bosphoro Thracio, L, III, cap. X (Toderini's footnote). Here the author alludes to Pietro Gillio, or Gyllius, De Bosphoro Thracio libri Tres (Lyon, 1561, 1st edn); republished Leiden: Elsevir, 1632 and 1635.

44 (d) See Turnefort, Relation d'un Voyage du Levant, Lett XV, T. II : p. 134 à Paris, 1717. In Chalcedon we cannot see such ruins and I could not find this marble stone (translation of Toderini's footnote). Here Toderini alludes to Joseph Pitton de Tournefort (1656-1708), Relation d'un voyage du Levant fait par ordre du Roy: contenant l'histoire ancienne et moderne de plusieurs isles de l'Archipel, de Constantinople, des côtes de la mer Noire, de l'Arménie, de la Géorgie, des frontières de Perse et de l'Asie mineure (...) (Paris: Imprimerie royale, 1717).

45 (e) Voy. par Spond. T. I. p. 267 à Lyon 1673 (Toderini's footnote). Here the author alludes to Jacob Spon (not Spond; 1647-1685); (Spon 1678).

46 Current transcription from Persian: Khusraw Parvīz (591-628 AD).

47 Current transliteration from Persian: Bārbād.

48 (a) In Herbelot, entry "Soavì" (translation of Toderini's footnote). For bibliographical reference on d'Herbelot, see above note 26.

49 Hagi Calfah is quoted many times by Toderini throughout the Letteratura: better known as Haji Khalifa or Kalfa, but also known as Kâtip Çelebi, and/or Mustafa 


\section{Giovanni De Zorzi}

bin Abdullah (1609-1657). He was a geographer and the author of the huge Kashf al-žnūn 'an asāmī al-kutub wa al-funūn (The Unveiling of the Shadows about the Titles of the Books and Arts), a bibliographical encyclopaedia in the Arab language with 14,500 books in alphabetical order, consulted very often by Toderini and his assistants.

50 Bibl. Arabico-Hispana, T. I. p. 347 (Toderini's footnote). For the common bibliographical abbreviations, Toderini refers here to Miguel Casiri (1710-1791), Bibliotheca Arabico-Hispana Escurialensis (Madrid: Antonius Perex de Soto, 1760-1770, 2 vols.); a huge catalogue of more than 1,800 Arabic manuscripts from the library of the Escorial.

51 Toderini's "muderìs" stands probably for Turkish müderris, a term commonly applied to a lecturer at a medrese. Validè Sultan, literally "mother Sultan", was the honorific title given to the mother of a Sultan.

52 (a) T. I. 1.c. vedi l'Andres, T. I. c. XI (Toderini's footnote).

53 Toderini refers here to the Spanish Jesuit Abbott Juan Andres (1740-1817).

54 (a) Abulfaragio Alì Ben Alhassani ben Moamed, in vol. 1 of the work entitled Great Repository of Tones, reports 150 small airs, together with the lives of 14 excellent musicians and four famous female singers: see Casiri, vol. 1, p. 347 (Toderini's footnote translated).

55 In the original, literally, "learned music". The best translation would be French musique savante, or musique littrèe, I have opted for "art music".

56 In the eighteenth century the Italian verb tastare (literally, "to touch") was applied to both keyboards and chordophones, implying both the touching and the plucking of the finger on a key, on a neck, on a string.

57 The author refers here to Chardin 1686.

58 Toderini probably alludes here to the circular diagrams of Arab-Persian musicology dawr (pl. adwār). For an overview, see Jean During: "Dawr" in Encyclopcedia Iranica, 1994, vol. VII, fasc. 2: 153-159.

59 Johann David Åkerblad (1763-1819), was a Swedish diplomat and Orientalist, and student of Silvestre de Sacy. From 1784 he resided in Constantinople and travelled from there throughout the Middle East.

60 Original: ne' tasti si trova la divisione de' tuoni. The neck of the Ottoman tanbûr is fretted by movable ligatures, which made visible the setting of pitches and thus the theoretical musical system immanent in Ottoman music.

61 Laminetta flessibile "thin flexible plate" is a curious definition for what we call, and was called during Toderini's times, a plectrum.

62 Here and below, when the author describes the zîl, we note a strange failure to use the term "cymbals" and its Italian organologic equivalent "piatti" that, nevertheless, existed from the sixteenth century.

63 Literally, "sonata". In this period "sonata" meant simply "what is played", from the verb suonare "to play".

64 Bairam (modern bayram) is a Turkish term that nowadays refers to collective festivals; in Toderini's times, the term applied to the well-known festivals for the end of Ramadan (Arabic, aid-ul fitr, Turkish, ramazan bayrami) and the Feast of Sacrifice (Arabic aid al-adha, Turkish kurban bayrami). Toderini (Letteratura, tome III, 43) explains that donalmà is a term given to public feasts and rejoicings (pubbliche feste, ed allegrezze), such as the departure of the fleet under the kapudan paşa.

65 Sic in the original text: it may be a publisher's error.

66 In the Mecmû' 'a-yi Saz ü Söz composed by Bobowski as a sketchbook for personal use under the reign of Sultan Murad IV (1612-1640), we certainly find a tune entitled Semāì Sultān Murād Han Fätih-i Baghdād, beginning with the verses "Gelsene 
Nesim-i Subh Ile", but this is not a Peşrev - commonly a serious and solemn instrumental genre - but rather a light, vocal semāì. Instead, we find an instrumental Pişrev- $i$ Şah Qulu.

67 Toderini, or the publisher, writes here "Meveli", instead of the more common, and correct, Mevlevì that we can read elsewhere in this same chapter.

68 Here used in its Latin sense, a place or space where people pray (oratorius from Latin orāre), normally distinct from the church. Toderini distinguishes between a mosque, a Mevlevì lodge (mevlevihâne, tekke), and the place in which they practised their ritual (samấ), which was called samâhâne.

69 Recueil de cent estampes de Mr Ferriol, p. 26. à Paris, 1714 (Toderini's footnote). Here the author refers to Ferriol 1714-1715. An analysis of the particular musical transcriptions quoted by Toderini would provide material for a separate article.

70 More appropriately in contemporary language: "microtones".

71 Toderini refers here to Pizzati 1782.

72 In the original: perché più abbondante di voci. Here the "voices" are the microtones and the richness that their presence brings to the melody.

73 The reference is to the composer, theoretician and Istria violin virtuoso, Giuseppe Tartini (1692-1770), always in touch with Franciscan Padre Giovanni Battista Martini (1706-1784).

74 Of course, Gottfried Wilhelm Leibniz (1646-1716) in a curious Italianization of his name.

75 This rather long passage by Miguel Casiri concerning the manuscripts is written in modern Latin.

\section{References}

Agop, G., Rudimento della lingua turchesca (Venice: Michiel'Angelo Barboni, 1685).

De Angélis, "Toderini, Gianbatista", in Biografia universale antica e moderna. Ossia storia per alfabeto della vita pubblica e privata di tutte le persone che si distinsero per opere, azioni, talenti, virtù e delitti. Opera affatto nuova compilata in Francia da una società di dotti, vol. 57 (Venice: Missiaglia, 1829).

Benetti, A., Osservazioni fatte dal fu dottor Antonio Benetti nel viaggio a Costantinopoli dell'illustriss. et eccellent. Sig. Gio. Battista Donado (Venice: Andrea Poletti, 1688).

Benetti, A., F. Flangini, S. Fortis and A. Paoluzzi, Raccolta Curiosissima di adagi turcheschi trasportati dal proprio idioma nell'italiano e latino dalli giovani di lingua sotto il bailaggio in Costantinopoli dell'illustr. ed eccell. Gio. Battista Donado, e indirizzata dai medesimi all'illustriss. Sig. Pietro, di lui figlio (Venice: Poletti, 1688).

Berengo, M., La società veneta alla fine del Settecento: ricerche storiche (Florence: Sansoni, 1956).

Cantimir, D., Histoire de l'Empire Othoman, où se voyent les causes de son aggrandissement et de sa decadence, translated into French by M. de Jonquieres (Paris: Le Clerc, 1743).

Chardin J., Journal du Voyage du Chevalier Chardin en Perse et aux Indes Orientales par la Mer Noire et par la Colchide (London: Moses Pitt, 1686).

Covel, J., Extracts from the Diaries of Dr. John Covel, 1670-1679, with Some Account of the Levant Company of Turkey merchants (London: Hakluyt Society, 1893).

de Ferriol, C., Recueil de cent estampes représentant les diverses nations du Levant (Paris: Le Hay \& Duchange Collambat, 1714-1715). 
104 Giovanni De Zorzi

de Lalande, J.J.L., Voyage en italie fait dans les années 1765 \& 1766 (Paris: chez Veuve Desaint, 1786), vol. 8.

De Zorzi, G., "In Constantinople among Music and Dervishes: Reports by European Travellers from the Sixteenth to the Eighteenth Century", Mawlana Rumi Review, 6 (Cambridge: Archetype, 2015), 36-66.

Della Valle, P., Viaggi di Pietro della Valle il Pellegrino descritti da lui medesimo in lettere familiari al suo erudito amico Pietro Schipano (Brighton: G. Gancia, 1843).

Donado, G.B., Della Letteratura dei Turchi. Osservazioni fatte da Gio. Battista Donado senator veneto fü bailo a Costantinopoli (Venice: Andrea Poletti, 1688).

du Loir, J.A., Les voyages du Sieur du Loir (Paris: Gervais Clovzier, 1654).

Firpo, L. (ed.) Relazioni di ambasciatori veneti al senato, vol. XIII: Costantinopoli (1590 1793) (Torino: Bottega d'Erasmo-Aldo Ausilio Editore, 1984).

Fonton, C., 1988-1889, "Essay Comparing Turkish Music with European Music [1751]", translation by Robert Martin, Turkish Music Quarterly, 1(2), 1-9; 2(1), 1-11.

Guer, J.A., Moeurs et usages des Turcs, leur religion, leur gouvernement civil, militaire et politique, avec un abrégé de l'histoire ottomane, par M. Guer (Paris: Coustelier, 1746-1747).

Guys, P.A., Voyage littéraire de la Grèce; ou, Lettres sur les Grecs, anciens et modernes, avec un parallèle de leurs moeurs. On y a joint un Voyage de Sophie à Constantinople, un voyage d'Italie, \& quelques opuscules du même (Paris: Duchesne, 1776).

Magni, C., Quanto di più curioso, e vago ha potuto raccorre Cornelio Magni nel primo biennio da esso consumato in viaggi, e dimore per la Turchia resta distribuito in questa prima parte in varie lettere scritte in Italia, le quali principalmente includono l'esame della metropoli di Costantinopoli, de' luoghi aggiacenti, e dell'esercito ottomano. Aggiontaui la relazione del Serraglio del Gran Signore, e delle parti più recondite di esso, distesa da Alberto Bobouio Leopolitano trattenutosi con nome di Bey in qualità di paggio (Parma: Galeazzo Rosati, 1679).

Moschini, G., Della letteratura Venicena del secolo XVIII fino à nostri giorni (Venice: Palese, 1806).

Niebuhr, C., Voyage en Arabie \& en d'autres pays circonvoisins (Amsterdam: S.J. Baalde/ Utrecht: J van Schoonven, 1776).

Paladino, G., "Due dragomanni veneti a Costantinopoli (Tommaso Tarsia e Gian Rinaldo Carli)", Nuovo Archivio Veneto, 33 (Venice: Tipografia C. Ferrari, 1917).

Pedani-Fabris, M.P. (ed.), Relazioni di ambasciatori veneti al senato, Costantinopoli, vol. XIV: Relazioni inedite (1512-1789) (Padova: Bottega d'Erasmo-Aldo Ausilio Editore, 1996).

Pedani-Fabris, M.P., "Le carte del sultano nell'Archivio di Stato di Venice", in M.P. Pedani and P. Bortolozzo (eds.), Le carte del sultano nell'Archivio di Stato di Venice. Catalogo della mostra/Venedik Devlet Arşivi'nde Bulunan Padişah Belgeleri. Sergi Kataloğu (Venice: Archivio di Stato di Venice, 2010).

Pizzati, G., La scienza de'suoni, e dell'armonia diretta specialmente a render ragione de' fenomeni, ed a conoscer la natura e le leggi della medesima, ed a giovare alla pratica del contrappunto (Venice: Gatti, 1782).

Preto, P., Venice e i turchi (Firenze: Sansoni, 1975).

Sommervogel, C., Bibliothèque de la compagnie de Jesus (Paris and Bruxelles: Schepens, 1890-1900), vol. VIII.

Spon, J., Voyage d'Italie, de Dalmatie, de Grèce et du Levant (Lyon: Cellier, 1678). 
Toderini, G., De la literature des Turcs, translated into French by the Abbott de Cournaud (Paris: Poincot, 1789).

Toderini, G., Litteratur der Türken. Aus dem Italianischen des Hern Abbé Toderini, Mit Zusätzen und Anmerkungen von Philipp Wilhelm Gottlieb Hausleutner (Königsberg: Friederich Nicolovius, 1790).

Toderini, D. (ed.), Tre dissertazioni dell'abate Giambattista Toderini veneto ex gesuita (Padua: Bettoni, 1810). 